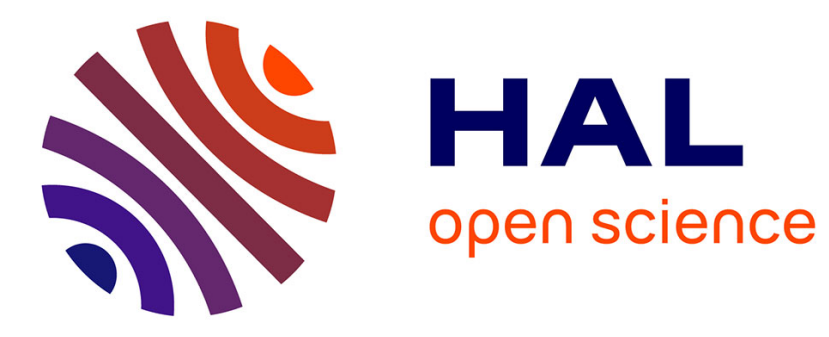

\title{
Glyphosate herbicide: is it as safe as we thought?
}

Natalia Montero, Vincent Fauvelle, Andrew Banks, Sarit Kaserzon, Jochen F Mueller

\section{To cite this version:}

Natalia Montero, Vincent Fauvelle, Andrew Banks, Sarit Kaserzon, Jochen F Mueller. Glyphosate herbicide: is it as safe as we thought?. Austral Ecology, In press, 10.1111/aec.12603 . hal-01768833

\section{HAL Id: hal-01768833 \\ https://hal.science/hal-01768833}

Submitted on 19 Apr 2018

HAL is a multi-disciplinary open access archive for the deposit and dissemination of scientific research documents, whether they are published or not. The documents may come from teaching and research institutions in France or abroad, or from public or private research centers.
L'archive ouverte pluridisciplinaire HAL, est destinée au dépôt et à la diffusion de documents scientifiques de niveau recherche, publiés ou non, émanant des établissements d'enseignement et de recherche français ou étrangers, des laboratoires publics ou privés. 


\section{Glyphosate herbicide: is it as safe as we thought?}

Natalia Montero, Vincent Fauvelle, Andrew Banks, Sarit Kaserzon, Jochen F. Mueller (Ikerbasque; Aix-Marseille Université; University of Queensland)

- Glyphosate is the most widely used broadspectrum herbicide and is not as innocuous as once thought.

- Studies reveal higher mobility of glyphosate in soils than expected and longer half-lives in soils and water.

- Mortality of non-target organisms at glyphosate levels found in the environment are not expected, but sublethal effects have been observed at very low concentrations.

- Regulatory authorities suggest there is no cancer risk to humans at realistic exposure levels, but studies on long-term effects are needed.

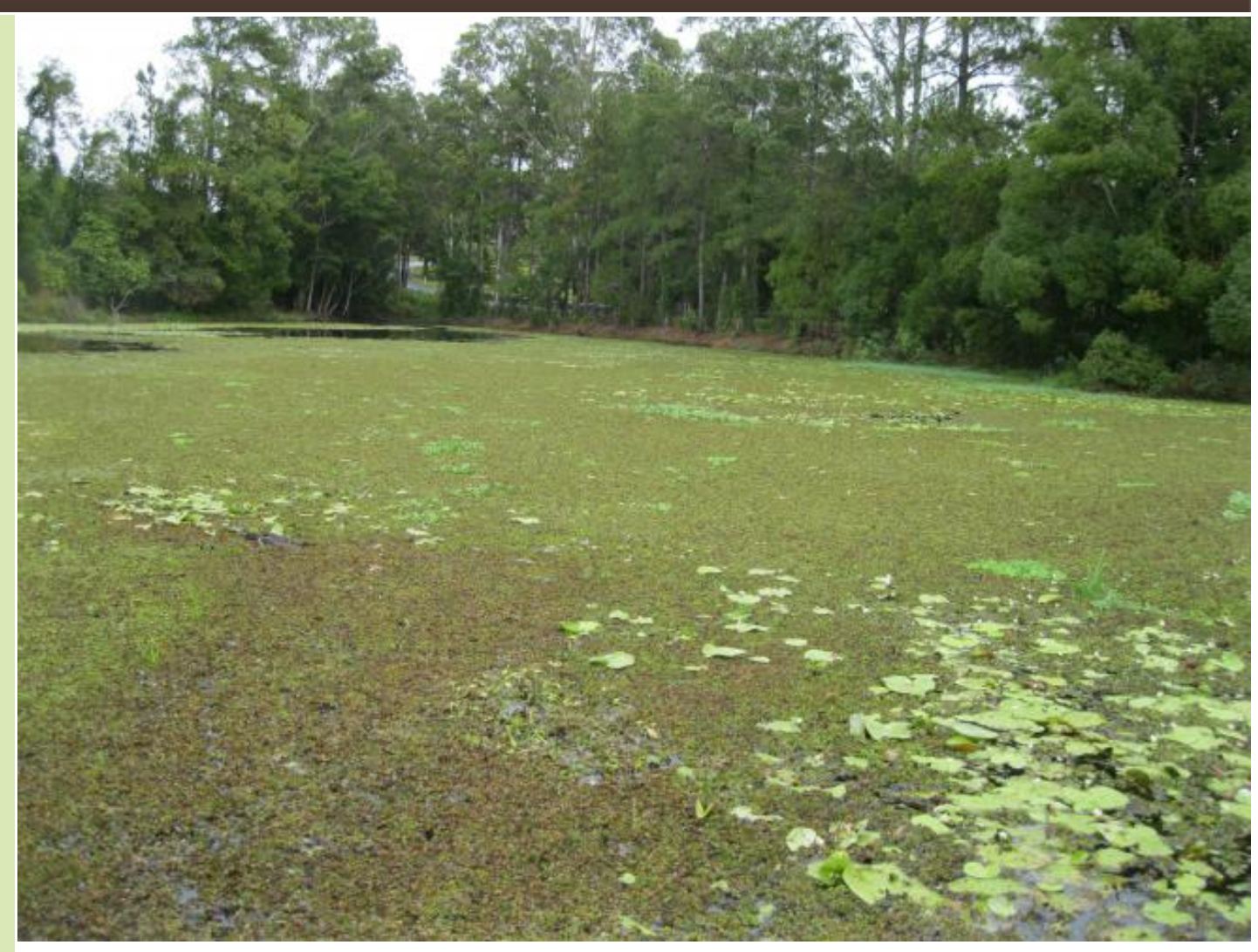

Glyphosate-based herbicides are widely used to control noxious aquatic weeds, raising concerns about contamination of aquatic ecosystems. Photo by N. Montero.

Glyphosate, the active ingredient of more than 750 herbicides, is the most widely used herbicide in Australia (15,000 tons/y) and worldwide (826,000 tons/y).

Glyphosate is considered environmentally safe due to its physico-chemical properties, presenting: (i) strong binding to soil; (ii) relatively rapid degradation; and (iii) potentially negligible risk to non-target organisms (mode of action specific to plants, fungi and some bacteria). However, studies reveal higher mobility of glyphosate in soils than expected and longer half-lives in soils (days-months) and water ( $<4-315$ days).

Generally, acute effects are not expected at glyphosate levels found in the environment. However, several sublethal effects have been observed in different organisms (rats, fish, amphibians, invertebrates) at glyphosate concentrations below regulatory guidelines: hepatorenal damage, endocrine disruption, reproductive impairment, genotoxicity,

\section{ecological ESA OF AUSTRALIA}

Ecological Society of Australia https://www.ecolsoc.org.au

\section{Further information about this topic contact:}

Natalia Montero
nmontero@azti.es
+34667102131
Chair, Hot Topics
Editorial Board
Dr Rachel Standish

morphological alterations, oxidative stress. Toxicity is species- and development-specific, with higher toxicity expected in amphibians and the early-life stages of organisms. In addition, the outbreak of glyphosate-resistant weeds (12 Australia; 32 worldwide) has led to increased use (multiple sprayings per season) of glyphosate, alone or combined with other herbicides. After the controversy arose in 2015, several regulatory authorities, in Australia and worldwide, concluded that glyphosate does not pose a carcinogenic risk to humans at realistic exposure levels.

Recent studies suggest that glyphosate-based herbicides are not as innocuous as expected. Some surfactants used in commercial formulations are more toxic than glyphosate itself. Thus, whole mixtures need to be evaluated to establish their potential risk. Comprehensive studies on the persistence of glyphosate in the environment and the associated chronic long-term effects, at population- and ecosystem-level, are still needed. 


\section{Supporting Evidence}

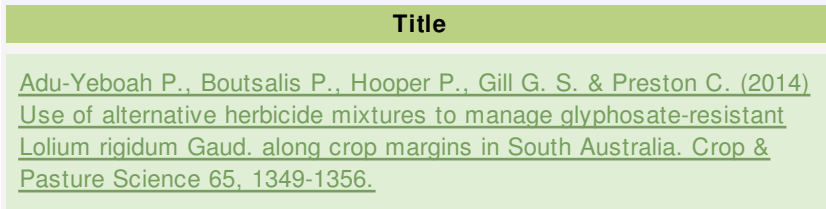

Amrhein N., Deus B., Gehrke P. \& Steinrücken H. C. (1980) The site of inhibition of the shikimate pathway by glyphosate. II. Interference of glyphosate with chorismate formation in vivo and in vitro. Plant Physiology 66, 830-834.

Annett R., Habibi H. R. \& Hontela A. (2014) Impact of glyphosate and glyphosate-based herbicides on the freshwater environment. Journal of Applied Toxicology 34, 458-479.

ANZECC/ARMCANZ (2000) Australian and New Zealand guidelines for fresh and marine water quality. Australian and New Zealand Environment and Conservation Council and Agriculture and Resource Management Council of Australia and New Zealand, $314 \mathrm{pp}$.

\section{Australian Glyphosate Sustainability Working Group (2016) Glyphosate} resistant weeds in Australia.

http://www.glyphosateresistance.org.au/database/index.php (accessed 20/10/2016).

Australian Pesticides and Veterinary Medicines Authority (2017) Final regulatory position: Consideration of the evidence for a formal reconsideration of glyphosate. Australian Government, $45 \mathrm{pp}$.

Bach N. C., Natale G. S., Somoza G. M. \& Ronco A. E. (2016) Effect on the growth and development and induction of abnormalities by a glyphosate commercial formulation and its active ingredient during two developmental stages of the South-American Creole $f$

Battaglin W. A., Meyer M. T., Kuivila K. M. \& Dietze J. E. (2014) Glyphosate and its degradation product AMPA occur frequently and widely in U.S. soils, surface water, groundwater, and precipitation. Journal of American Water Resources Association 50, 275

\section{Aim}

To examine a range of herbicide options to control infestations of glyphosate-resistant annual ryegrass (AR) along crop margins.

To investigate what is the mode of action of glyphosate in plants and bacteria, in vivo and in vitro.

(i) To present the current exposure data of glyphosate and glyphosate-based herbicides in the aquatic environment and (ii) to critically evaluate our current understanding of their effects in aquatic organisms.

To provide an authoritative guide for setting water quality objectives required to sustain current or likely future environmental values for natural and semi-natural water resources in Australia and New Zealand.

To list glyphosate resistant weeds in Australia.

To assess the latest information of glyphosate (IARC monograph, risk assessments of regulatory agencies and expert international bodies) to determine whether there are sufficient scientific grounds to warrant placing the chemical under formal reconsideration.

To assess the lethal and sublethal effects of Roundup ULTRA® MAX and technical-grade glyphosate on the Gosner stages (Gss 25 and 36 ) of the frog Leptodactylus latrans larvae through the use of acute toxicity bioassays.

To broadly summarize glyphosate and AMPA occurrence and concentration in water and sediment samples collected in 2001 through 2010 from diverse hydrologic settings and a wide geographic range of locations in the United States.

\section{Key Results}

AR populations growing at all four sites had 12-24 fold resistance to glyphosate compared with a standard susceptible population in doseresponse experiments. Mixtures of paraquat+diquat+diuron, glufosinate ammonium+diuron and two applications of paraquat+diquat 14 days apart consistently provided high levels of control $(>90 \%$ reduction in seed-head production) of glyphosateresistant $A R$ at all locations.

Glyphosate inhibits a step in the biosynthetic sequence from shikimate to chorismate, as demonstrated by the accumulation of shikimate in glyphosate treated buckwheat hypocotyls and $G$. mollugo cells. The same was also observed in cell-free extracts of $A$. aerogenes.

Sensitivity to glyphosate and the constituents of commercial formulas is highly speciesspecific, but the primary source of toxicity can be attributed to surfactants. Acute toxicity is highly species dependant across all taxa, with toxicity depending on the timing, magnitude and route of exposure. Amphibians are particularly sensitive to environmental exposure. More investigation is required to determine the long-term effects of GBH exposure in the aquatic environment.

N/A

Since 1996, 12 glyphosate resistant weeds, 8 grass species and 4 broadleaf species have been documented.

Exposure to glyphosate does not pose a carcinogenic or genotoxic risk to humans. There are no scientific grounds for placing glyphosate and products containing glyphosate under formal reconsideration. The APVMA will continue to maintain a close focus on any new assessment reports or studies that indicate that this position should be revised.

Both technical-grade glyphosate (GLY) and Roundup ULTRA® MAX produced sublethal effects on L. latrans tadpoles, but RU was five orders of magnitude more toxic than GLY. $R U$ induced sublethal effects on all the experimental endpoints evaluated, which could affect to the fitness and survival of frogs. Adverse impacts on the fitness of anuran larvae inhabiting agroecosystems can be expected at environmentally relevant concentrations.

Glyphosate and AMPA are usually detected together, mobile, and occur widely in the environment. Glyphosate (median $<0.02 \mu \mathrm{g} / \mathrm{L}$; maximum $476 \mu \mathrm{g} / \mathrm{L}$ ) and AMPA (median 0.04 $\mu \mathrm{g} / \mathrm{L}$; maximum $397 \mu \mathrm{g} / \mathrm{L}$ ) were detected frequently in soils and sediment, ditches and drains, precipitation, rivers and streams; and less frequently in lakes, ponds, and wetlands: soil water and groundwater. 
Benbrook C. M. (2016) Trends in glyphosate herbicide use in the United States and globally. Environmental Sciences Europe 28:3.

Borggaard O. K. \& Gimsing A. L. (2008) Fate of glyphosate in soil and the possibility of leaching to ground and surface waters: a review. Pest Management Science 64, 441-456.

Contardo-Jara V., Klingelmann E. \& Wiegand C. (2009) Bioaccumulation of glyphosate and its formulation Roundup Ultra in Lumbricus variegatus and its effects on biotransformation and antioxidant enzymes. Environmental Pollution 157, 57-63.

Cuhra M., Bøhn T. \& Cuhra P. (2016) Glyphosate: too much of a good thing? Frontiers in Environmental Science 4:28.

\section{Cuhra M., Traavik T. \& Bøhn T. (2013) Clone-and age-dependent} toxicity of a glyphosate commercial formulation and its active ingredient in Daphnia magna. Ecotoxicology 22, 251-262.

de Castilhos Ghisi N. \& Cestari M. M. (2013) Genotoxic effects of the herbicide Roundup $\AA$ in the fish Corydoras paleatus (Jenyns 1842) after short-term, environmentally low concentration exposure. Environmental Monitoring and Assessment 185, 3201-3207.

\section{Folmar L. C., Sanders H. O. \& Julin A. M. (1979) Toxicity of the} herbicide glyphosate and several of its formulations to fish and aquatic invertebrates. Archives of Environmental Contamination and Toxicology 8, 269-278.
To present trends in glyphosate use to help in the understanding of the risks and benefits of the use of glyphosate based herbicides.

(i) To highlight the state of knowledge on glyphosate fate in soils and (ii) to identify areas where more research is needed because of limited or inconclusive data.

To investigate if a sediment living organism, such as L. variegatus is negatively influenced by an exposition to pure glyphosate and the formulation Roundup Ultra (RUU) in surface waters.

(i) to review specific aspects of the history, chemistry and safety of glyphosate and glyphosate-based herbicides (GBHs) and (ii) to provide insights into the shortcomings of current regulatory framework of GBHs.

To test the acute and chronic toxicity of Roundup (RU) and glyphosate (isopropylamine salt of glyphosate; IPA) to Daphnia magna.

To evaluate the genotoxic potential of Roundup $\AA(R U)$ to blood and liver cells in the Neotropical fish Corydoras paleatus following short-term exposure to an environmentally realistic concentration of the herbicide.

(i) To evaluate the toxicity of technical grade glyphosate, the isopropylamine salt of glyphosate (IPA), Roundup (RU) and the RU surfactant to four species of aquatic invertebrates and four species of fish by means of acute toxicity tests and (ii) to determine the sublethal effects of $R U$ and the isopropylamine salt of glyphosate on reproduction, avoidance reactions and invertebrate stream drift.
The emergence of glyphosate resistant weeds led to the increase of the number of applications of glyphosate and the amount sprayed. Other factors favouring the increase on the use of glyphosate are (i) the increase in number of glyphosate-tolerant crops, (ii) its use to speed up the harvesting of crops and (iii) the declining price. Total worldwide glyphosate use has increased 12-fold from 1995 (67 million kg) to 2014 (826 million kg).

Sorption of glyphosate in soils depends of different physico-chemical factors. The major path of degradation of glyphosate in soils is mediated by bacteria. There is a high variability in the half-life times of glyphosate in soils, ranging from few days to years, depending on the characteristics of soils. Glyphosate leaching and surface runoff is mainly determined by soil structure and rainfall.

Glyphosate accumulated in L. variegatus after exposure to both substances, the pure glyphosate and the RUU. Both substances enhanced the enzymatic activity, but this alteration was stronger after exposure to RUU. The commercial formulation RUU induced oxidative stress in L. variegatus. The formulation RUU is of more ecotoxicological relevance than the glyphosate itself.

Glyphosate is not a single chemical, it is a family of compounds with different chemical, physical and toxicological properties.

Glyphosate is increasingly recognized as having more profound toxicological effects than assumed from previous assessments. Based on current knowledge, restrictions to the use of GBHs should be applied, to ensure that are used sensibly and with moderation, until more efficient, cost-effective and less harmful alternatives are found.

RU (EC50=3.7-10.6 mg a.i /L) showed slightly lower toxicity than IPA (EC50=1.4-7.2 mg a.i/L) alone in acute tests, whereas negative and serious effects (reduced juvenile size, increased mortality, high abortion) were observed at very low $\mathrm{RU}$ concentrations $(<0.45-1.35 \mathrm{mg} / \mathrm{L})$ in chronic tests. If more conservative EC50 were used, glyphosate would be classified as 'toxic' or 'moderately toxic' to aquatic invertebrates.

The piscine micronucleus (PMT) test did not show differences between the control and the exposed organisms. The comet assay showed a high rate of DNA damage in groups exposed to RU (in blood and hepatic cells). Short-term exposure to the pesticide $R U$ is genotoxic to C. paleatus, even at a relatively low concentration.

Acute toxicities for RU ranged 2.3- $43 \mathrm{mg} / \mathrm{L}$. Apart from increasing the toxicity of glyphosate, the surfactant was the primary toxic compound in RU. Fish exposed to RU (2 $\mathrm{mg} / \mathrm{L}$ ) presented glyphosate in fillets ( 80 $\mathrm{mg} / \mathrm{kg}$ ) and eggs $(60 \mu \mathrm{g} / \mathrm{kg})$. Increased stream drift of midge larvae was observed after exposure to $R U$ but not to isopropylamine. 
Giesy J. P., Dobson S. \& Solomon K. R. (2000) Ecotoxicological risk assessment for Roundup $\AA$ herbicide. Reviews of Environmental Contamination and Toxicology 167, 35-120.

Guilherme S., Gaivão I., Santos M. A. \& Pacheco M. (2010) European eel (Anguilla anguilla) genotoxic and pro-oxidant responses following short-term exposure to Roundup $\AA$ - a glyphosate-based herbicide. Mutagenesis 25, 523-530. (i) To review the current state of knowledge on the ecological toxicity of Roundup (RU) and glyphosate and (ii) to consider this information in a comprehensive ecological risk assessment.

To evaluate the genotoxic potential of Roundup $\AA(R U)$ to blood cells of fish (Anguilla anguilla), following short-term exposure to environmentally realistic concentrations, addressing its possible association with oxidative stress.

To evaluate the sublethal effects of

Harayashiki C. A. Y., Varela A. S. Jr., Machado A. A., Cabrera Lda. C. Primel E. G. Bianchini A. \& Corcini C. D. (2013) Toxic effects of the herbicide Roundup in the guppy Poecilia vivipara acclimated to fresh water. Aquatic Toxicology 142-143, 176-184.
Roundup (RU) on a suite of reproductive and biochemical parameters in the Brazilian guppy Poecilia vivipara.
Mensah P. K., Palmer C. G. \& Odume O. N. (2015) Chapter 4: Ecotoxicology of glyphosate and glyphosate-based herbicides- Toxicity to wildlife and humans, In: Toxicity and Hazard of Agrochemicals, Larramendi M. (Ed.), InTech, 93-112.

\section{Mercurio P., Flores F., Mueller J. F., Carter S. \& Negri A. P. (2014)} Glyphosate persistence in seawater. Marine Pollution Bulletin 85, 385390.
To review the impacts of glyphosate and glyphosate-based herbicides (GBHs) on wildlife and humans using measured endpoint effects caused by genotoxicity, cytotoxicity and reproductive toxicity.

To quantify the persistence of glyphosate in seawater in standard tests but under natural conditions and at environmentally relevant concentrations.
Mesnage R., Arno M., Costanzo M., Malatesta M., Séralini G-E. \& Antoniou M. N. (2015a) Transcriptome profile analysis reflects rat liver and kidney damage following chronic ultra-low dose Roundup exposure. Environmental Health 14:70.
To obtain insight into the alterations in gene expression profiles associated with the exposure to ultra-low concentrations of Roundup (RU).

To provide a review of effects of glyphosate and its formulations on laboratory mammals below regulatory limits.

\section{Mesnage R., Defarge N., Spiroux de Vendômois J., Séralini G. E. (2015b) Potential toxic effects of glyphosate and its commercial formulations below regulatory limits. Food and Chemical Toxicology 84 , 133-153.}

Pérez G. L., Vera M. S. \& Miranda L. A. (2011) Chapter 16: Effects of herbicide glyphosate and glyphosate-based formulations on aquatic ecosystems, In: Herbicides and Environment, Kortekamp A. (Ed.), InTech, 343-368.

Glyphosate tends to bind tightly to soil, being essentially unavailable to plants or soil organisms. Acute effects of the surfactant are greater than glyphosate alone for aquatic animals. Minimal acute and chronic risk for non-target terrestrial organisms is expected. Use of RU for aquatic restoration is safe, but application rate, depth of water and vegetation coverage should be considered.

Present data demonstrated the $R U$ genotoxic potential to blood cells of $A$. anguilla exposed to environmentally realistic concentrations. The herbicide induced both DNA damage and cytogenetic effects. Antioxidants were unresponsive to $R U$, indicating that oxidative stress caused by this herbicide in blood was not severe. Environmentally relevant concentrations of $\mathrm{RU}$ can pose a health risk for fish populations.

Exposure to RU reduced the sperm quality in the guppy $P$. vivipara. $R U$ did not affect the biochemical parameters in adults of $P$. vivipara. Exposure to environmentally relevant concentrations of RU may negatively affect at long-term the reproduction of $P$. vivipara, with consequent changes in fish populations inhabiting environments contaminated with the herbicide.

Glyphosate and its formulations may not only be considered as having genotoxic, cytotoxic or endocrine disrupting properties but they may also be causative agents or reproduction abnormalities in both wildlife and humans.

Degradation of glyphosate was mediated by the bacteria present in the flasks. Half-lives of glyphosate in seawater was light-dependant, ranging from 47 , at low light levels, to 315 days in the dark. In the marine environment, glyphosate is moderately persistent under low light conditions and highly persistent in the dark. During flood plumes in the tropics, dissolved and sediment-bound glyphosate might be delivered far from shore.

Gene disturbances reflect a liver and kidney lipotoxic condition and increased cellular growth. Observed alterations in gene expression confirm pathology observations made at an anatomical, histological and biochemical level. Chronic exposure to glyphosate based herbicides at an ultra-low, environmental dose, can result in liver and kidney damage with potential significant health implications for animal and human populations.

Higher toxicity is caused by the adjuvants present in the commercial formulations than by glyphosate. Sublethal effects (endocrine disruption, oxidative stress, cellular damage), especially affecting the liver and kidneys might be expected after exposure to commercial formulations below regulatory levels. Further studies are needed to investigate the risk of glyphosate and its formulations, especially at levels below regulatory limits and over longer durations (chronic studies).

(i) To provide an overview of direct and indirect effects of glyphosate and commercial formulations of glyphosate on aquatic ecosystems and (ii) to present a revision of their toxicity to non-target species (algae, aquatic plants, protozoa, crustaceans, molluscs, fish and amphibians).
Glyphosate and its formulations are hazardous for the aquatic environment. Toxicity depends on environmental factors, type of organism and its life stage. Sublethal endpoints are more sensitive indicators of effects than mortality. Glyphosate itself exerts less toxicity to aquatic organisms than the surfactant POEA present in commercial formulations. 
Puértolas L., Damásio J., Barata C., Soares A. M. V. M. \& Prat N. (2010) Evaluation of side-effects of glyphosate mediated control of a giant reed (Arundo Donax) on the structure and fuction of a nearby Mediterranean river ecosystem. Environmental Resea

Relyea R. A. (2005) The impact of insecticides and herbicides on the biodiversity and productivity of aquatic communities. Ecological Applications 15(2), 618-627.

Séralini G-E., Clair E., Mesnage R., Gress S., Defarge N., Malatesta M., Hennequin D. \& Spiroux de Vendômois J. (2014) Republished study: long-term toxicity of a Roundup herbicide and a Roundup-tolerant genetically modified maize. Environmental Sciences

Stachowski-Haberkorn S., Becker B., Marie D., Haberkorn H., Coroller . \& De la Broise D. (2008) Impact of Roundup on the marine microbial community, as shown by an in situ microcosm experiment. Aquatic Toxicology 89, 232-241.

Uren Webster T. M. U. \& Santos E. M. (2015) Global transcriptomic profiling demonstrates induction of oxidative stress and of compensatory cellular stress responses in brown trout exposed to glyphosate and Roundup. BMC Genomics 16:32.
To evaluate the effect of the application of the herbicide Herbolex (glyphosate as active ingredient) to control giant reed (Arundo donax) on the structure and function of a nearby river ecosystem.

To investigate the impact of two insecticides (carbaryl and malathion) and two herbicides (2,4-D and glyphosate) on the diversity of the communities in an outdoor aquatic mesocosms and on the survival and biomass of each taxon in the community.

(i) To investigate the health effects associated to the consumption of Rounduptolerant genetically modified (GM) maize (with or without Roundup (RU) application) and the exposure to $R U$ in drinking water, in a study performed for 2 years in rats, (ii) to compare the results with the short-term study performed by Monsanto in similar conditions but for 90 days and (iii) to determine if low doses of full commercia $\mathrm{RU}$ formulation at permitted levels were toxic.

To examine the effects of Roundup (RU), at environmentally relevant concentrations, on marine microbial communities by means of microcosms in situ.

To investigate and compare the global transcriptional responses to glyphosate and Roundup (RU) in the liver of female juvenile brown trouts (Salmo trutta).
Macroinvertebrate communities (number of taxa, abundance) were not affected by herbicide application. Specific toxic effects on transplanted D. magna (feeding inhibition, oxidative stress) and field collected $\mathrm{H}$. exocellata (oxidative stress) were observed at glyphosate concentrations ranging 20-137 $\mu \mathrm{g} / \mathrm{L}$.

Species richness was reduced with Sevin $(15 \%)$, malathion (30\%) and glyphosate (22\%) Glyphosate (3.8 mg/L) and 2,4-D did not have effects on periphyton, zooplankton, insect predators or snails. However, Roundup (RU) eliminated two species of tadpoles and nearly exterminated a third species. Current application rates of $\mathrm{RU}$ can be highly lethal to many species of amphibians.

The consumption of GM maize with or without $\mathrm{RU}$ application or $\mathrm{RU}$ alone gave similar pathologies in rats. The observed disease in kidney and liver may result from endocrine disruptive effects. All treatments enhanced large tumour incidence in both sexes, but especially mammary tumours in female rats.

The herbicide RU can affect natural coastal microbial communities after a 7-d exposure at $1 \mu \mathrm{g} / \mathrm{L}$ for prokaryotes and at $10 \mu \mathrm{g} / \mathrm{L}$ for some picoeukaryotes. Glyphosate pollution during run-off events can modify microbial communities in some coastal areas.

Observed transcriptional changes are consistent with generation of oxidative stress and the induction of compensatory cellular stress response pathways. There was an increase in cell proliferation and cellular turnover, and an up-regulation of metabolic processes. Glyphosate and RU induce oxidative stress in fish, including at concentrations measured in the environment. 